Diabetologia 9, 492-498 (1973)

(C) by Springer-Verlag 1973

\title{
Clinical Trial with Monocomponent Lente Insulins
}

Preliminary Report

\author{
B. Bruni, M. D’Alberto, M. Osenda, C. Ricci and G.L. Turco* \\ Ospedale Maria Vittoria-Clinica Medica, Centro di Studi Fisico-Biologici, Università di Torino
}

Received: September 20, 1972; and in revised form: July 30, 1973

Summary. The immunogenicity of pork Monocomponent (MC) Lente insulin (Monotard ${ }^{\circledR}$ ) was studied for more than one year in a clinical trial series of 43 insulin-dependent diabetics in comparison with Monospecies (MS) Lente pork insulin ( $5 \times$ crystallized, not monocomponent). The antigenicity was estimated by determination of total extractable serum insulin by radioimmunoassay and of I-125 insulin-binding of the serum IgG measured by radioimmunoelectrophoresis. MC Lente insulin was nonimmunogenic in newly diagnosed diabetics: at the end of the observation, the antibody titre was generally under the level of detection. Long-term diabetics transferred to MC Lente insulin from conventional insulin preparations showed a marked reduction in the high initial levels of insulin antibodies, sometimes with a multiphasic pattern; low initial levels remained unchanged at the end of the trial. MS Lente insulin was found to be, even if weakly, immunogenic in newly diagnosed diabetics. In long-term insulin-treated diabetics transferred to MS Lente insulin a tendency to reduction in the high antibody starting level was often observed. Diabetic manifestations such as high insulin requirement, insulin allergy, insulin lipoatrophy and diabetic microangiopathy showed - in somo instances - a clinical course independent of immunological modifications. Clinical control of diabetes achieved both with MC and MS Lente insulins was rated as good. There was no ketosis or severe hypoglycaemia, and the daily insulin requirement was reduced in several cases.

Key words: Monocomponent lente insulin, monospecies lente insulin, insulin immunogenicity, insulin antibodies, high insulin requirement, insulin allergy, insulin lipoatrophy, diabetic microangiopathy, clinical control of diabetes.
"Immunogenicity" of an insulin preparation is currently defined as the ability of the insulin to induce the formation of humoral and cellular antibodies in animals or in insulin-treated patients.

Since the papers of Raynaud and Lacroix, 1925; Barral and Roux, 1931 ; Bernstein et al., 1938; Wasserman, Broh-Kahn and Mirsky, 1940; Jorpes, 1940; Arquilla and Stavitsky, 1956; Moinat, 1957; Berson and Yalow, 1957, the central problem concerns the question of whether the insulin molecule has, per se, even weak immunogenic properties or whether these properties are related to protein "impurities" contained in commercial preparations.

The experimental work and the first clinical investigations of Schlichtkrull and associates (19681972) led to the conclusion that:

a) the insulin molecule is not immunogenic; b) the production of antibodies in subjects treated with conventional insulin preparations is not solely due to species differences, but rather to other peptides related to insulin which contaminate the crystalline extracts of beef or pork insulin (mainly the a- and b-Steiner components: Pro-Insulin Like Components and Insulin Like Components).

The term "Monocomponent insulin" (MC-Insulin) is used by Schlichtkrull, 1972 to designate Sanger's insulin purified from a- and b-components and resolved from c-Steiner's component, to become the sole protein

* With the technical assistance of B.C. Brossa, A. Bachiorlini, A. Giolitti. of the preparation "with little or no immunogenic activity when used for therapy". This concept was based on extensive studies in rabbits and humans.

Nevertheless, in the opinion of Fankhauser and associates (1971), although pork MC-insulins are the least immunogenic insulins so far used and the impurities (a- and b-components) are the most prominent factor in the insulin antibody production, the immunogenicity of insulin itself cannot be excluded with full certainty. Furthermore, according to Deckert and Grundahl, 1970, pure pig insulin crystals are not immunogenic if injected in a neutral solution corresponding to the $\mathrm{pH}$ of the body fluids.

The purpose of the present investigation was to compare the antigenicity of the Lente prepared from MC-pork insulin (MC Lente or Monotard $\left.{ }^{\circledR}\right)$ with that of Monospecies, non-monocomponent, Lente prepared from $5 \times$ crystallized, pork insulin (MS Lente) in patients with:

a) newly diagnosed insulin-dependent diabetes, never previously treated with insulin;

b) long-term, conventionally insulin-treated diabetes presenting clinical conditions such as high insulin requirement, insulin allergy, insulin lipoatrophy, and diabetic microangiopathy, which may possibly accompanied by an increased rate of antibody formation.

An additional aim of the investigation was to get information about the quality of clinical control of the diabetes as achieved with MC or MS Lente insulin. 


\section{Material and Methods}

Since December 1970 and up to August 1972, 43 insulin-dependent diabetic subjects of both sexes, aged 5 to 65 years, were submitted to treatment with Novo MC Lente and Novo MS Lente insulins. The patients were divided in the following groups:

Group 1: 6 new insulin-requiring diabetics (never previously treated with insulin) treated with $\mathrm{MC}$ Lente.

Group 2: 5 new insulin-requiring diabetics treated with MS Lente.

Group 3: 18 long-term diabetics, previously treated with conventional types of insulin, transferred to $\mathrm{MC}$ Lente. The preferential criteria for selection were clinical conditions as listed above.

Group 4: 14 long-term diabetics, previously treated with conventional types of insulin, transferred to MS Lente. Selection criteria as in group 3.

Cooperative patients were hospitalized for a fortnight for full examination and therapy. They were on a daily diet of $2000-2500 \mathrm{kcal}(20 \%$ proteins, $40 \%$ fats and $40 \%$ carbohydrates) and returned for oncemonthly control after the hospitalization.

The immunogenicity of the insulin preparations was estimated by determination of:

1. total extractable serum insulin by radioimmunoassay (total IRI) according to Heding (1972); normal values: $0-25 \mu \mathrm{U} / \mathrm{ml}$;

2. specific insulin-binding capacity of serum $\operatorname{IgG}$ ( $\mathrm{IgG}$ binding) according to the radioimmunoelectrophoresis method of Hein Christiansen (1973). $30 \mu \mathrm{l}$ of a I-125-pork insulin solution $(20 \mathrm{mU} / \mathrm{ml}$, specific activity $20 \mathrm{mCi} / \mathrm{mg}$ ) was mixed with patient's serum and barbital buffer in equal proportion and incubated overnight at $+4 \mathrm{C} .5 \mu \mathrm{l}$ of the mixture was applied to the holes of an agarose gel plate containing commercial preparation of antihuman IgG from rabbits. The plate was then transferred to the electrophoresis chamber; electrophoresis was run at $2-3 \mathrm{~V} / \mathrm{cm}$ during $15-20 \mathrm{~h}$. "Cigar-shaped" precipitates containing the insulin bound to the precipitated IgG fraction, were cut out and transferred to a well gamma counter for counting the radioactivity of IgG-bound insulin. Limits of sensitivity: normal sera showed $\operatorname{IgG}$ binding values of about $0.05 \mathrm{mU} / \mathrm{ml}$; diabetic sera were accepted as positive at values above $0.10 \mathrm{mU} / \mathrm{ml}$. Autoradiography of the precipitates was used only to get a qualitative evaluation of the presence and location of the tracer of the precipitates. Radioinsulin and antisera were supplied by Novo Research Institute, Copenhagen. This method has proved suitable ranking of the sera for routine clinical purposes (Schlichtkrull et al., 1972; Andreani et al., 1972). As for the binding of Iodinelabelled insulin: cf. Federlin (1971).

The usual clinical and biochemical data were recorded on standard trial case record sheets: history, age, sex, duration of diabetes, previous treatment, occurrence of other endocrine diseases, fasting blood sugar (true glucose: $\mathrm{mg} / 100 \mathrm{ml}$ ), M-value (during hospitalization), urine glucose excretion $(\mathrm{g} / 24 \mathrm{~h})$, proteinuria, ketonuria, body weight, clinical remarks on complications, diet, and the current insulin treatment.

At the beginning of treatment and during periods of readjustment, MC or MS Actrapid insulins were used occasionally as a supplement to or a substitute for the treatment with MC or MS Lente.

\section{Results}

\section{Immunological Situation}

Group 1: New patients treated with 16-36 Units of MC Lente daily showed, after 300-500 days of treatment, zero or barely detectable IgG insulin binding values $(0.05-0.10 \mathrm{mU} / \mathrm{ml})$. In 3 patients, however, IgG binding reached maximal levels of $0.4 \mathrm{mU} / \mathrm{ml}$ during the early period of treatment. The total IRI displayed practically the same pattern (Fig. 1).

Group 2: New patients treated with 12-32 Units of MS Lente daily showed, after the same period of observation, a rise in the $\operatorname{IgG}$ binding values above the level of detection up to $1.10 \mathrm{mU} / \mathrm{ml}$, with a corresponding pattern of total IRI (Fig. 2).

Group 3: A marked drop in high initial levels of $\operatorname{IgG}$ binding values was observed in the majority of patients after the transfer from conventional to $\mathrm{MC}$ Lente insulin. The high starting levels of total IRI also fell. As Fig. 3 shows, a multiphasic pattern with transient increases - especially in total IRI - is evident in some cases. After about 400 days, values tend to diminish even if not quite to the normal level. Cases with low initial antibody levels, did not have relevant variations at the end of the trial.

Group 4: In patients treated with conventional insulin and transferred to MS Lente, the levels of IgG binding and total IRI, which were initially high, also tended to decrease, as shown in Fig. 4 . At various points during the study, however, more or less evident peaks of IgG binding and IRI values were noted. Low IgG binding and total IRI starting levels remained unchanged or presented intercurrent rises of the abovementioned type.

\section{Clinical Situation}

The clinical-metabolic control of diabetes after a year or more on MC and MS Lente insulins was rated good in all cases. Fasting blood sugar did not exceed $200 \mathrm{mg} / 100 \mathrm{ml}$; glucosuria was within $20-25 \mathrm{~g} / 24 \mathrm{~h}$, except for one case; M-values during hospitalization were under $15-20$; ketonuria was generally absent; 
no episodes of keto-acidosis or hypoglycaemic shock occurred. Even in cases with a rapid drop in antibody titres, hypoglycaemia was reported only in the form of mild reactions. Complications such as infections, surgery and pregnancy had no outward effect on the course of the diabetes. An improvement in the sub. jective state was frequently recorded.
Insulin Lipoatrophy. After a year of treatment with MC Lente there was a complete absence of lipoatrophy in the sites of insulin administration. In two patients there was an almost complete remission of lipoatrophy caused by the previous treatment. One patient experienced a fall in total IRI and IgG binding; the other had low starting antibody levels.

Table 1. Daily insulin requirement before and after 1 year of treatment with $M C$ and $M S$ Lente. Le=Lente; $R I=$ Regular Insulin; $P Z I=$ Protamine-Zinc-Insulin; $R A=$ Rapitard

\begin{tabular}{|c|c|c|c|c|}
\hline \multirow{2}{*}{\multicolumn{2}{|c|}{ Group 3: }} & \multicolumn{3}{|c|}{ Total insulin dose: $\mathrm{U} / 24 \mathrm{~h}$} \\
\hline & & before & \multicolumn{2}{|l|}{ after } \\
\hline patient $\mathrm{n} .1$ & P.G. of age 35 & 28 & 16 & Le MC \\
\hline patient n. 2 & P.C. o age 32 & 28 & 24 & Le MC \\
\hline patient n. $\mathbf{3}$ & R.A. og age 38 & 40 & 44 & Le MC \\
\hline patient n. 4 & C.G. $q$ age 19 & 52 & 44 & Le MC \\
\hline patient $\mathrm{n} . \overline{5}$ & L.C. O age $\mathbf{1 5}$ & $40+20 \mathrm{Le}$ & $44+20$ & $0 \mathrm{Le} \mathrm{MC}$ \\
\hline patient n. 6 & R.M. & $48 \quad$ Le & 40 & Le MC \\
\hline patient $n .7$ & S.P. 0 age 24 & 60 & 44 & Le MC \\
\hline patient n. 8 & T.A. O age 24 & $36+20 \mathrm{Le}$ & 32 & $\mathrm{~L} \theta \mathrm{MC}$ \\
\hline patient n. 9 & S.R. o age 44 & $40 \quad$ Le & 28 & Le MC \\
\hline patient n. 10 & M.G. $A$ age 5 & $8+8 R I$ & 10 & Le MC \\
\hline patient n. 11 & A.G. 12 & 34 & 32 & Le MC \\
\hline patient $\mathrm{n} .12$ & B.C. o age 56 & 36 & $32+$ & 8 Le MC \\
\hline patient n. 13 & P.L. Q age 35 & PZI & 36 & Le MC \\
\hline patient n. 14 & B.E. o age 57 & $20+20 \mathrm{RI}$ & 24 & Le MC \\
\hline patient n. 15 & D.A. \& age 39 & Le & 36 & Le MC \\
\hline patient n. 16 & F.G. O age 18 & $36+20 \mathrm{PZI}$ & 32 & $\mathrm{Le} \mathrm{MC}$ \\
\hline patient n. 17 & R.M. + age 17 & Le & 24 & Le $\mathrm{MC}$ \\
\hline patient n. 18 & B.S. ô age 20 & 60 & 54 & Le MC \\
\hline \multicolumn{5}{|l|}{ Group 4: } \\
\hline patient $\mathrm{n} .1$ & P.G. o* age 45 & 28 & 12 & Le MC \\
\hline patient $n .2$ & P.E. $q$ age 55 & 32 & 28 & Le MC \\
\hline patient n. 3 & A.M. ㅇ age 55 & $12+12 \mathrm{RI}$ & 36 & Le MC \\
\hline patient n. 4 & C.R. age 20 & $44+24 \mathrm{Le}$ & 24 & $\mathrm{Le} \mathrm{MC}$ \\
\hline patient n. 5 & B.S. of age 13 & Le & 28 & Le MC \\
\hline patient n. 6 & P.T. & Le & 36 & Le MC \\
\hline patient $n .7$ & C.R. O age 42 & PZI & 40 & $\mathrm{Le} \mathrm{MC}$ \\
\hline patient n. 8 & C.A. of age 13 & $36+16 \mathrm{RA}$ & 44 & Le MC \\
\hline patient $n .9$ & R.A. O age $\mathbf{2 3}$ & $\mathrm{Le}+12 \mathrm{RI}$ & 28 & $\mathrm{Le} \mathrm{MC}$ \\
\hline patient n. 10 & B.M. of age 15 & $\mathrm{Le}+10 \mathrm{RI}$ & 40 & Le MO \\
\hline patient n. 11 & P.A. age $\mathbf{1 2}$ & Le & 36 & $\mathrm{Le} \mathrm{MC}$ \\
\hline patient $n .12$ & P.A. O age 20 & $40+16 \mathrm{RA}$ & 40 & Le MC \\
\hline patient n. 13 & R.L. $q$ age 36 & 32 & 24 & Le MC \\
\hline patient n. 14 & P.E. ơ age 19 & $14+16 \mathrm{RA}$ & 44 & $\mathrm{Le} \mathrm{MC}$ \\
\hline
\end{tabular}

No differences were noted in the quality of control between the groups treated with MC and MS Lente insulins.

The following clinical details deserve special consideration because of their possible relation to the immunological situation.

Insulin Requirement. No correlation could be established between the behaviour of antibody level and the change in the daily insulin dose. Nevertheless, a reduction in insulin requirement in groups 3 and 4 was possible as shown in Table 1.

Insulin Allergy. Prior insulin allergy of the immediate local and generalized type disappeared in 3 cases after transfer to MC Lente. A related fall in the serum insulin antibodies was found in 2 cases.
Microangiopathic complications. A decrease in the serum insulin antibodies was observed in 4 cases. The clinical situation did not, however, present any significant changes.

\section{Conclusions}

The following conclusions may be drawn from our preliminary results.

1. The association of the two methods employed (Total IRI and I-125-IgG binding) seems to be suitable for assessing the level of circulating insulin antibody as a clinical routine. 
2. Monocomponent Lente pork insulin was found to be "non immunogenic" in newly diagnosed insulindependent diabetics at the end of a treatment period for more than one year; slight transient antigenic effect was occasionally observed only in the initial phase of therapy. The disappearance or the reduction in the level of circulating antibodies in patients transferred to MC Lente insulin after years of treatment with
In comparison to MC Lente insulin, MS Lente insulin seems to possess a slightly greater immunogenic activity.

Our data agree with the preliminary results reported in 37 cases by Korp and Levett (1973); and in 48 cases, by Andreani et al. (1972).

4. The course of elinical conditions (such as insulin hyposensitivity, insulin allergy, insulin lipoatrophy,

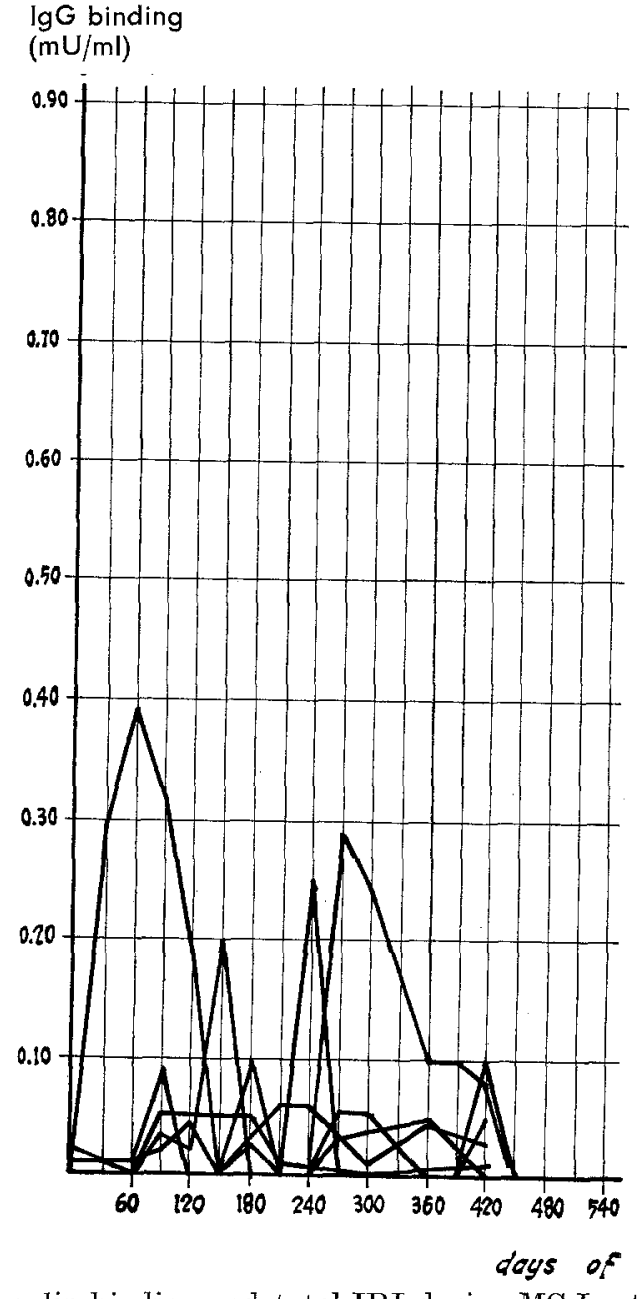

Total IRI

$(\mu \mathrm{U} / \mathrm{ml})$

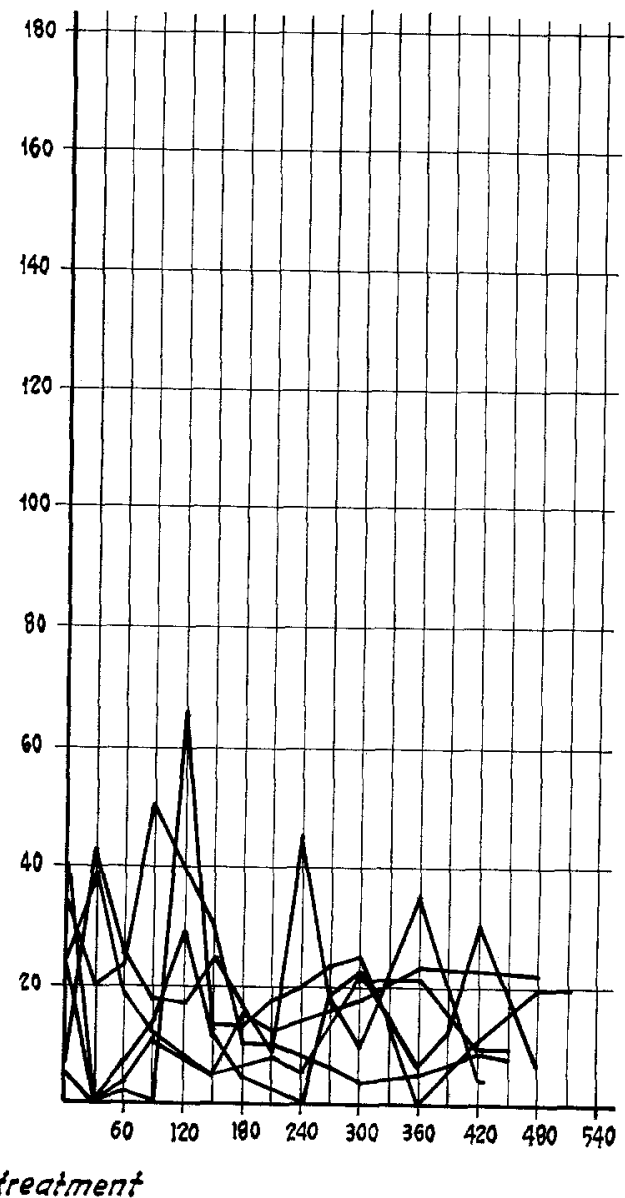

Fig. 1. IgG insulin binding and total IRI during MC Lente treatment in patients not previously treated with insulin. (Group 1)

conventional insulin preparations agrees with the general impression of an important change in the immunological state.

3. Monospecies Lente pork insulin appears to be, even if weakly, immunogenic as demonstrated in cases of newly diagnosed insulin-dependent diabetes. In some cases of long-term diabetes, previously treated with conventional insulin preparations, a downward trend in serum antibody levels after transfer to MS Lente was observed. and diabetic microangiopathy) was in several instances independent of modifications in the immunological state.

5. A good clinical-metabolic control of diabetes, even in cases of brittle diabetes, very difficult to compensate before the trial, was obtained in nearly all the cases of our series, with a reduction of the daily insulin dose. 


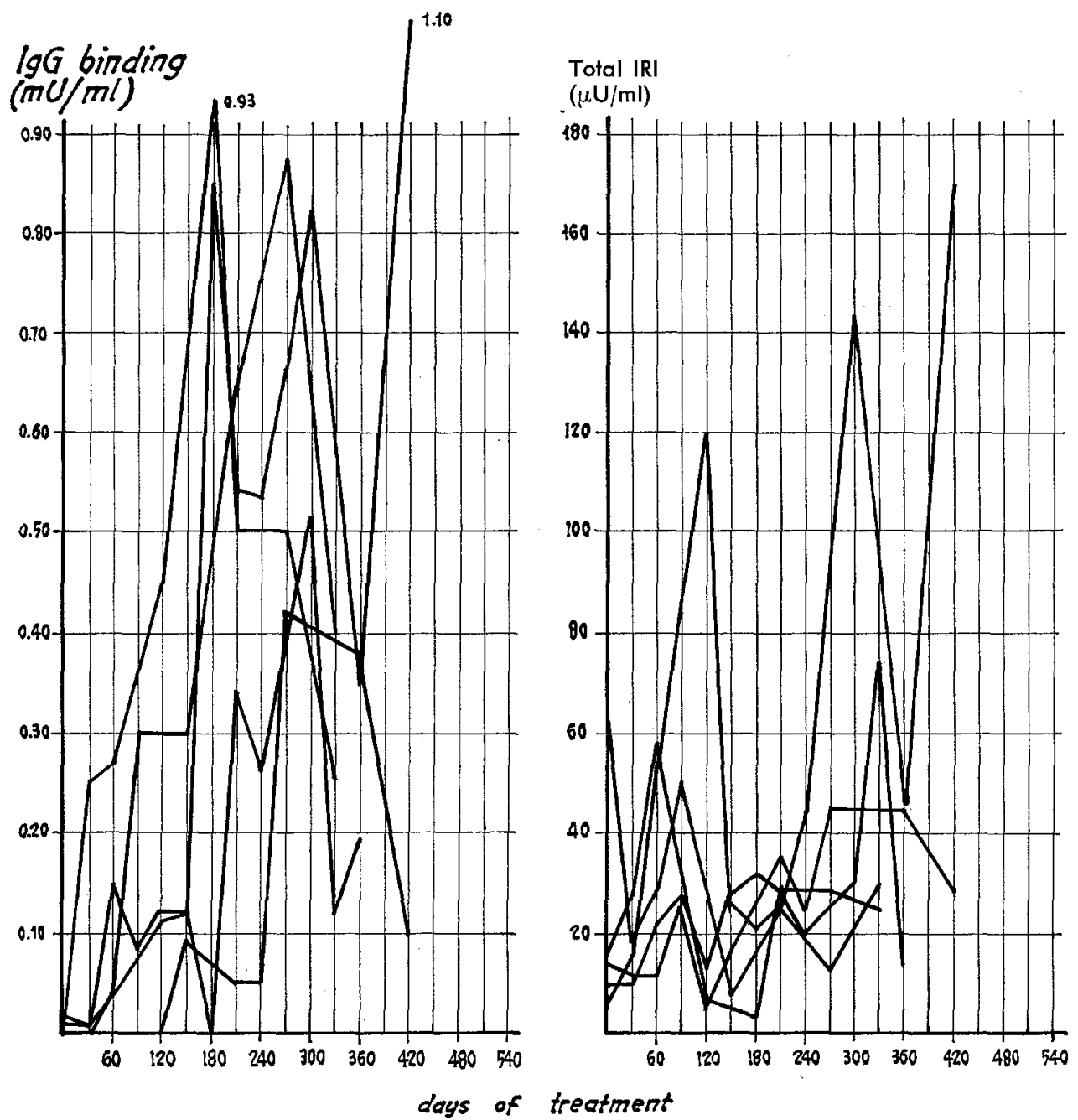

Fig. 2. IgG insulin binding and total IRI during MS Lente treatment in patients not previously treated with insulin (Group 2)

Acknowledgement. We are greatly indebted to Dr. Sc. J. Schlichtkrull; and to Dr. H. Fornet and Coworkers of the Novo Research Institute, Copenhagen, for their helpful support during these studies.

\section{References}

Andreani, D., Iavicoli, M., Colletti, A., Menzinger, G., Maltarello, C.: Esperienze sul trattamento del diabete con le insuline di tipo Monocomponente (MC) e Monospecie (MS). Folia endocr. (Roma) 25, 516-539 (1972)

Arquilla, E.R., Stavitsky, A.B. : Evidence for the insulindirected specificity of rabbit anti-insulin serums. $\mathbf{J}$. clin. Invest. 35, 467-473 (1956)

Barral, P., Roux, J.: L'insuline constitue-t-elle-mème un antigène spécifique? Séances Soc. Chim. Biol. 106, $292-296(1931)$
Bernstein, C., Kirsner, J.B., Turner, W.J.: Studies on anaphylaxis with insulin. J. Lab. clin. Med. 32, 938$945(1938)$

Berson, S.A., Yalow, R.S.: Studies with insulin-binding antibody. Diabetes 6, 402-405 (1957)

Deckert, T., Grundahl, E.: The antigenicity of pig insulin. Diabetologia 6, 15-20 (1970)

Fankhauser, S., Michl, J.: New possibilities to avoid the formation of insulin-antibodies in diabetic patients. Diabetologia 7, 478 (1972) Abstr.

Federlin, K.: Immunopathology of insulin. Berlin-Heidelberg-New York: Springer Verlag 1971

Heding, L.G.: Determination of total serum insulin (IRI) in insulin-treated diabetic patients. Diabetologia $\mathbf{8}$, $260-266$ (1972)

Hein Christiansen, Aa., Munkgaard Rasmussen, S., Völund, A.: Levels of insulin-binding immunoglobulins in 


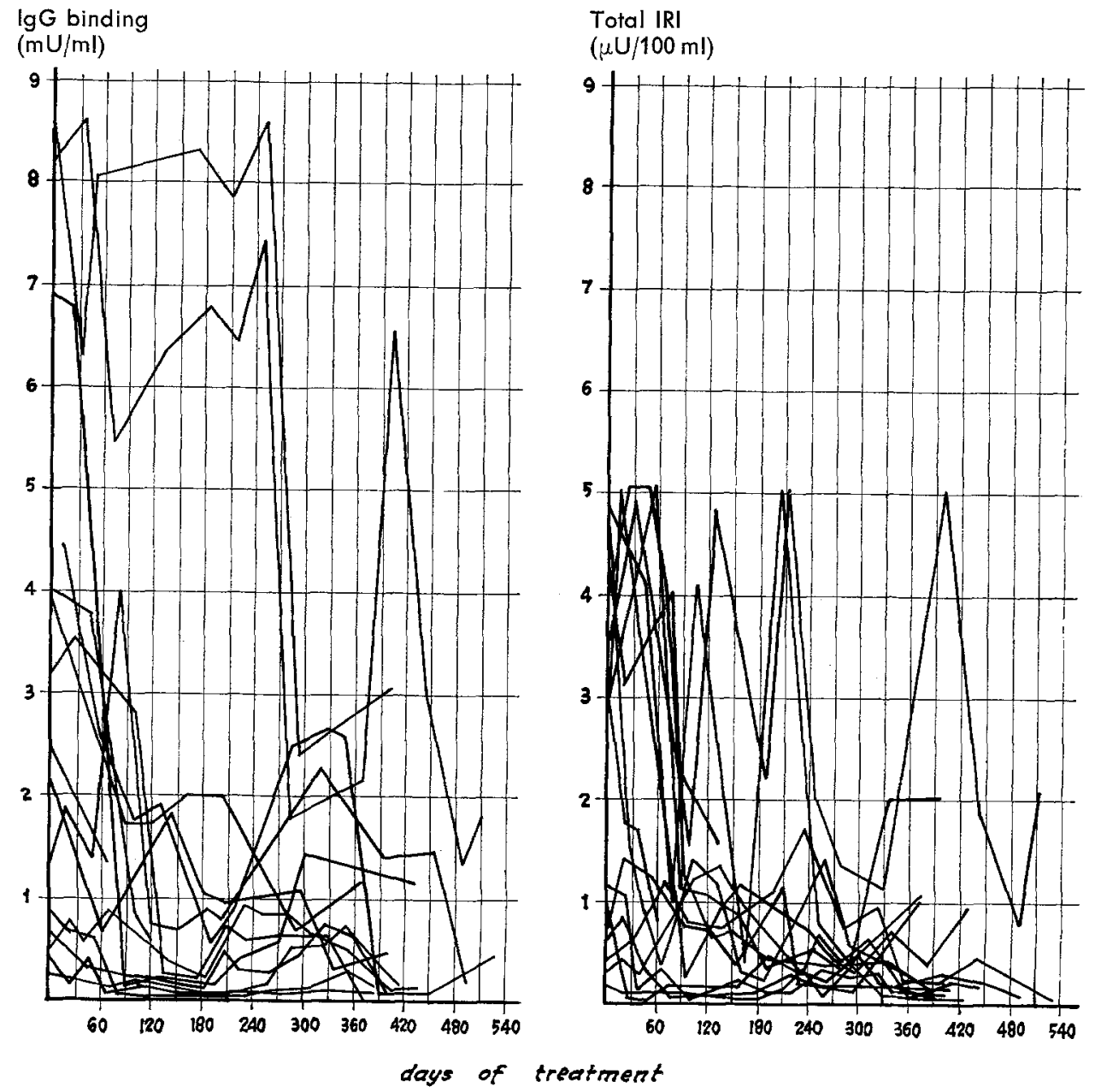

Fig. 3. IgG insulin binding and total IRI during MC Lente treatment in patients previously treated with conventional insulins (Group 3)

diabetics compared with clinical data. Diabetologia 7 , 474 (1972) Abstr

Hein Christiansen, Aa.: Radioimmunoelectrophoresis in the determination of insulin binding to $\mathrm{Ig}^{\mathrm{G}} \mathrm{G}$. Methodological studies. Horm. Metab. Res. 5, 147-154 (1973)

Korp, W., Levett, R.E. : Erfahrungen mit Monokomponenten-Insulin. Wien. klin. Wschr. 85, 326-330 (1973)

Jorpes, J.E.: Recrystallized insulin for diabetic patients with insulin allergy. Arch. intern. Med. 83, 363-371 (1949)

Moinat, P.: A quantitative estimation of antibodies to exogenous insulin in diabetic subjects. Diabetes 7, $462-467$ (1958)

Raynaud, M., Lacroix, A.: Un cas d'anaphylaxie a l'insuline. Essai de pathogénie des oedèmes insuliniens. Bull. Soc. med. Hop. Paris 49, 831-832 (1925)

Schlichtkrull, J., Munck, O., Jersild, M.: The M value. An index of blood sugar control in diabetics. Acta med. scand. 177, 95-102 (1965)

Schlichtkrull, J., Brange, J., Ege, H., Hallund, O., Heding, L. G., Jörgensen, K., Markussen, J., Stahnke, P., Sundby, F., Völund, A.: Proinsulin and related proteins. Diabetologia 6, 80 (1970) Abstr.

Schlichtkrull, J., Heding, G., Hein Christiansen, Aa., Völund, A.: Immunological aspects of insulin therapy. Lecture held at the 7 th Acta Endocrin. Congr. Copenhagen July 1971

Schlichtkrull, J., Brange, J., Hallund, O., Hein Christiansen, Aa., Heding, L.G., Jörgensen, K.H.: Highly purified insulin for therapy. Lecture held at the 8. ème Réunion Ann. Ass. Suisse du Diab. Lausanne, January 1972

Schlichtkrull, J., Brange, J., Hein Christiansen, Aa., Hallund, O., Heding, L.G., Jörgensen, K.H.: Clinical 
lgG binding

$(\mathrm{mU} / \mathrm{ml})$

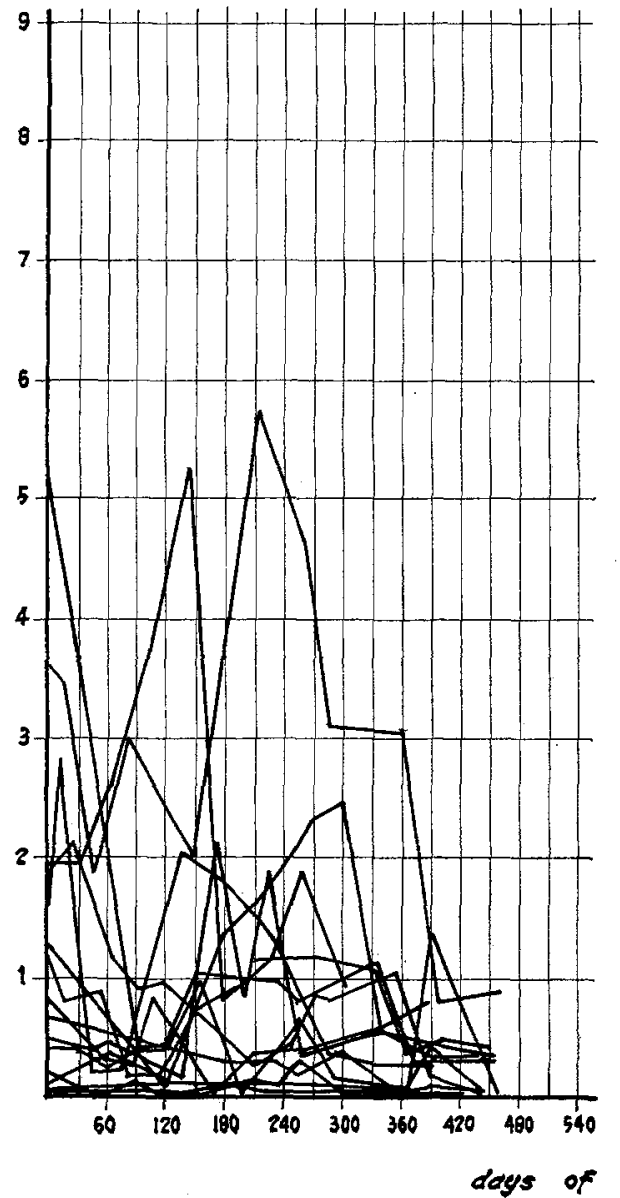

Total IRI

$(\mu \mathrm{U} / 100 \mathrm{ml})$

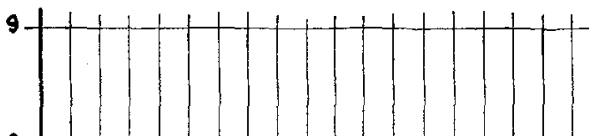

8
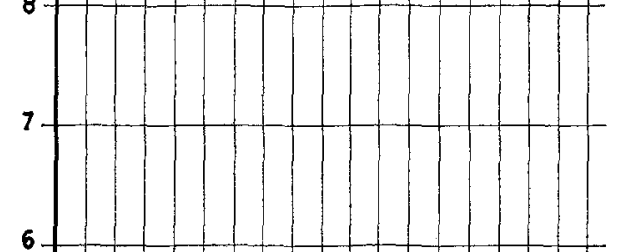

6
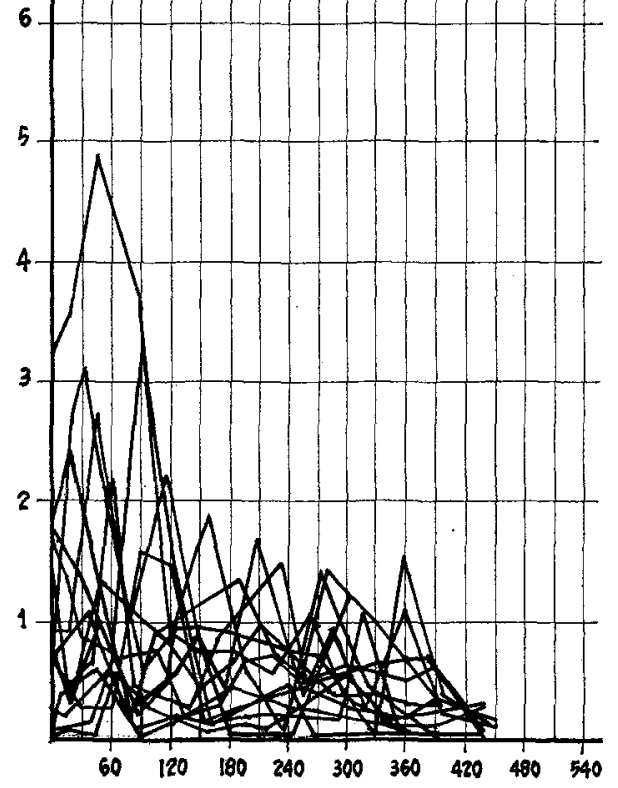

Fig. 4. IgG insulin binding and total IRI during MS Lente treatment in patients previously treated with conventional insulins (Group 4)

aspects of insulin-antigenicity. Diabetes 21, Suppl. 2, $649-656(1972)$

Steiner, D.F., Hallund, O., Rubenstein, A., Cho, S., Bayliss, C.: Isolation and properties of proinsulin, intermediate forms, and other minor components from crystalline bovine insulin. Diabetes 17, 725 - 736 (1968)

Wasserman, P., Broh-Kahn, R.H., Mirsky, I.A.: The antigenic property of insulin. J. Immunol. 28, 213-224 (1940)
Prof. Dr. B. Bruni

Ospedale Maria Vittoria

Via Cibrario 72 (10144)

Torino

Italy 